\title{
Ureteral reconstruction with abdominal wall muscle flap: experimental study in rabbits
}

\section{Uso de retalho muscular de parede abdominal para reconstrução ureteral. Estudo experimental em coelhos}

\author{
Nelson Alfred Smith ${ }^{1}$; Paulo Cesar Silva²; Manoel luiz Ferreira²; Alberto Schanaider, TCBC-RJ²
}

A B S T R A C T

The authors detail the experimental development of a technique for the reconstruction of the ureter using a tubular shape, muscle flap of the abdominal wall. the preliminary results indicate the feasibility of this surgical technique.

Key words: Ureter. Surgical Flap. Abdominal Wall.

\section{INTRODUCTION}

T raumatic lesions of the ureter are relatively frequent events and may be caused by iatrogenic lesions, most often after gynecological or urological operations, or after blunt or penetrating abdominal trauma. Some techniques can be employed for the treatment of such lesions, ranging from uretero-enterostomy to ileal interposition ${ }^{1-4}$. Muscle flaps have long been experimentally studied as substitutes for segments of the urinary tract ${ }^{5}$.

In this study we describe a ureteral reconstruction technique using a myoperitoneal flap made with elements of the abdominal wall.

\section{TECHNIQUE}

We used six New Zealand White, male rabbits, weighing $3 \mathrm{~kg}$. The anesthetic medication consisted of ketamine (35 mg/kg) and xylazine (5 mg/kg) intramuscularly in the pre-anesthesia, followed by general anesthesia induction and maintenance with inhaled isoflurane and $100 \%$ oxygen in an open system.

Upon completion of a suprapubic laparotomy and dissection of the ventral abdominal wall, we manufactured a pedicled muscle flap, irrigated by the epigastric vessels, with approximately $3 \mathrm{~cm}$ wide and $5 \mathrm{~cm}$ in length (Figure 1).

The flap was shaped in a tubular fashion over a catheter, so that the inner surface was aponeurotic, and the peritoneal surface, external. Then, after resection of approximately $0.5 \mathrm{~cm}$ from the dorsal bladder wall, the bladder was anastomosed to the distal end of the muscle tube.
After section of the ureter at the junction of the middle third with the distal one, we catheterized the ureter cranially with a $1 \mathrm{~mm}$-diameter polypropylene catheter, so that it was positioned inside the muscular tube, reaching the bladder. Then, to reestablish the urinary transit, we sutured the cranial segment of the ureter to the proximal opening of the muscular tube (Figure 2).

We administered analgesics postoperatively for five days and observed the animals' body posture. We daily performed surgical wound inspection and palpation of the abdomen in the the renal fossa area to assess the kidney size. We also observed the appearance and quantity of urine. We performed autopsy on the 60th day of the postoperative period, with on-site verification of the urinary structures.

This project was approved by the Ethics Committee on Animal Use - CEUA - Experimental Surgery Laboratory, Department of Surgery, Faculty of Medicine, Federal University of Rio de Janeiro - FM-UFRJ.

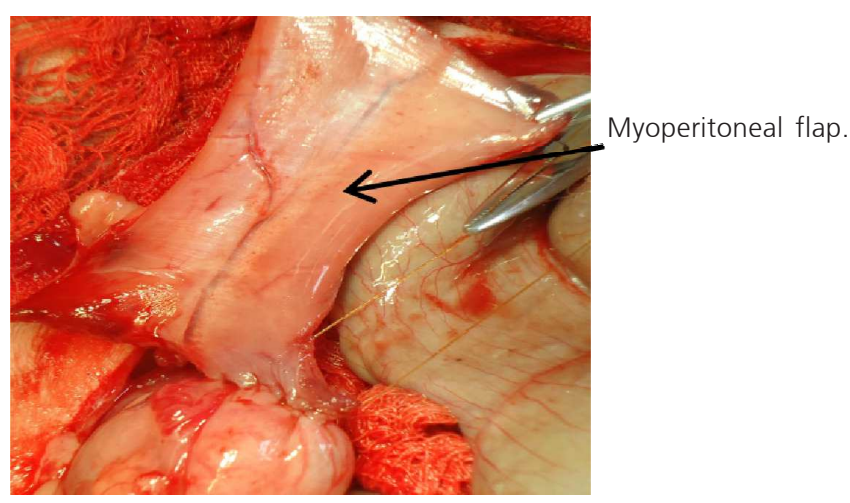

Figure 1 - Pedicled muscle flap, with epigastric vessel (arrow).

1. Department of Surgery, Faculty of Medicine, Federal University of Rio De Janeiro, Rio de Janeiro - RJ, Brazil; 2. Experimental Surgery Center, Department of Surgery, Faculty of Medicine, Federal University of Rio De Janeiro, Rio de Janeiro - RJ, Brazil. 


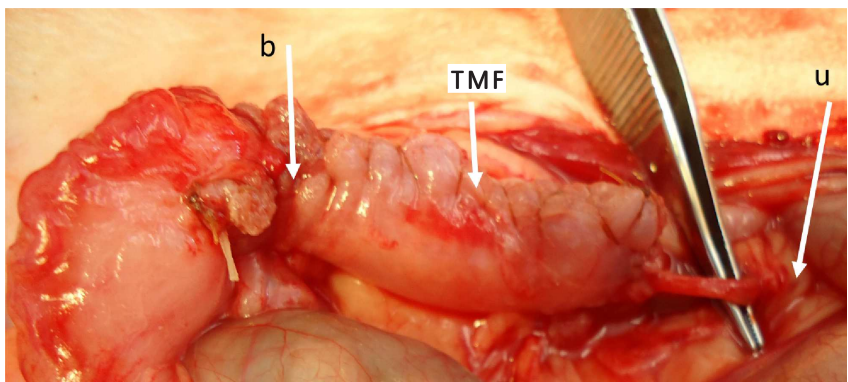

Figure 2 - $\quad$ Tunneled muscle flap (TMF) sutured to the bladder (B) and to the remaining segment of the ureter $(U)$.

\section{DISCUSSION}

Ureteral injury is a complication that can occur after any abdominal or pelvic surgery, or endoscopic maneuver ${ }^{1,2}$.

Its treatment varies depending on the affected ureteral segment and the functional status of renal unit ${ }^{2,3}$. Depending on the injured segment, various ureteral reconstruction techniques can be used ${ }^{3,4}$. In cases of severe tissue devitalization or compromise of a large ureteral segment, extreme measures are necessary, such as the renal autograft or ileal transposition ${ }^{4,6}$, which can replace a segment or the entire ureter ${ }^{7-12}$.

In this study, the application of pedicled muscle flap from the abdominal wall set in a tubular form for the partial reconstruction of the ureter was adequate. On examination of the surgical wound we did not observe infection or dehiscence. There was the emergence of incisional hernia in the donor area of the pedicled muscle flaps, the urine showed normal appearance and color, and the animals urinated normally. At necropsy, there was preservation of the anatomical structures and sustained permeability of the lumen of the muscular tube.

Thus, according to the results obtained in this study, the use of a tunneled muscle flap of the abdominal wall for the partial replacement of a ureteral segment is a viable technique and can be an alternative in the reconstruction of ureteral segments.

\section{R E S U M O}

Os autores detalham o desenvolvimento experimental de uma técnica para a reconstrução do ureter, utilizando um retalho muscular da parede abdominal, na forma tubular. O resultado preliminar indica a viabilidade desta técnica operatória.

Descritores: Ureter. Retalhos Cirúrgicos. Parede Abdominal.

\section{REFERENCES}

1. Selzman AA, Spirnak JP. Iatrogenic ureteral injuries: a 20-year experience in treating 165 injuries. J Urol. 1996;155(3):878-81.

2. Brooke JB, Pearle MS. Complications of ureteroscopy. Urol Clin N Am. 2004;31(1):157.

3. Gupta V, Sadasukhi TC, Sharma KK, Yadav RG, Mathur R, Tomar $V$, et al. Complete ureteral avulsion. ScientificWorldJournal. 2005:5:125-7.

4. Benson MC, Ring KS, Olsson CA. Ureteral reconstruction and bypass: experience with ileal interposition, the Boari flap-psoas hitch and renal autotransplantation. J Urol. 1990;143(1):20-3.

5. Sadove RC, Rodgers JB, Fink BF, McRoberts JW. Experimental rectus abdominis myocutaneous and rectus abdominis myoperitoneal flaps as urinary bladder wall substitutes in miniature swine. Plast Reconstr Surg. 1993;91(3):511-21.

6. Boxer RJ, Fritzsche P, Skinner DG, Kaufman JJ, Belt E, Smith RB, et al. Replacement of the ureter by small intestine: clinical application and results of the ileal ureter in 89 patients J Urol. 1979;121(6):72831.

7. Monti PR, Lara RC, Dutra MA, de Carvalho JR. New techniques for construction of efferent conduits based on the Mitrofanoff principle. Urology. 1997;49(1):112-5.
8. Ali-el-Dein B, Ghoneim MA. Bridging long ureteral defects using the Yang-Monti principle. J Urol. 2003;169(3):1074-7.

9. Lytton $B$, Schiff $M$. Interposition of an ileal segment for repair of ureteral injuries. J Urol. 1981;125(5):739-41.

10. Chung BI, Hamawy KJ, Zinman LN, Libertino JA. The use of bowel for ureteral replacement for complex ureteral reconstruction: longterm results. J Urol. 2006;175(1):179-83; discussion 183-4.

11. Armatys SA, Mellon MJ, Beck SD, Koch MO, Foster RS, Bihrle R. Use of ileum as ureteral replacement in urological reconstruction. J Urol. 2009;181(1):177-81.

12. Smith N, Medeiros M, Vieira G. Complete ureteral avulsion: ileal ureteral substitution wth an unusal proximal ileal anastomosis. BJUI [Internet]. 2010 Dez. Disponível em: http://www.bjui.org/ contentfullitem. aspx?ld=586.

Received 02/02/2014

Accepted for publication 05/05/2014

Conflict of interest: none.

Source of funding: none.

Mailing address:

Nelson Alfred Smith

E-mail:nalfredsmith@gmail.com 